九州大学学術情報リポジトリ

Kyushu University Institutional Repository

\title{
Extraction of tourist behavior contexts from blog by verbs and their objects
}

Nakatoh, Tetsuya

Research Institute for Information Technology, Kyushu University

Hirokawa, Sachio

Research Institute for Information Technology, Kyushu University

http://hdl. handle. net/2324/776801

出版情報: Proc. IIAI Int. Conf. Adv. Appl. Informatics, IIAIAAI, pp.112-116, 2012-12-14 バージョン：

権利関係 : 


\title{
Extraction of Tourist Behavior Contexts from Blog by Verbs and Their Objects
}

\author{
Tetsuya Nakatoh and Sachio Hirokawa \\ Research Institute for Information Technology, \\ Kyushu University. \\ Email: \{nakatoh, hirokawa\}@cc.kyushu-u.ac.jp
}

\begin{abstract}
Blog articles by tourists contain interesting and personal experiences of where and how they have gone, what they have done and what they thought. Such individual experiences are helpful in many cases compared to the general and official information about the tourist resort by tourist agents. However, it is not easy to choose related articles and to extract still more nearly required information from these unsorted blog articles. This paper proposes a technique of feature extraction by dependency analysis of verbs and objects in those sentences that describe tourist's behavior. This paper applied the method to $7,917,385$ blog articles on Kyushu area and reports some analysis on "where and what did they eat" as case studies.
\end{abstract}

\section{INTRODUCTION}

The tourist resorts and the touristic institutions have special feature on their own. However, it is not easy to give a potential visitor that information. The tourist agencies already have been making advertisements and campaigns using media in order to get many tourists to come, before the Internet age. Now, they are making an effort to let many people know the special feature of the area or a store using the sightseeing portal site and the original Web page. Some tourists choose a destination using these pieces of Web information, and are enjoying the special feature of the visited area.

On the other hand, blog articles have the information about different individual experience from the information distributed officially. The tourist who actually went to the tourist resort may find by himself the special feature seldom known in addition to the known special feature got in advance, and may enjoy it. Or by a visitor's viewpoint, they may have the information and evaluation which are different from the offer side about the existing special feature. Such the special feature and information that were experienced by the tourist are based on personal experience, and were only shared only among very familiar persons before. However, generally they came to be exhibited by the blog article which described an individual travel record and individual experience now. Such information found out by the tourists is useful also for the tourist that the destination will be decided, the tourist agent who wants to improve the type of service and also for the self-governing body which wants to find out the new special feature of tourism.

However, it is not easy to extract the information appropriately from the blog articles indicated without being arranged, and to use it. In this paper, description of tourists' action
(Tourist Behavior) in blog articles attracted attention. Specifically, the analysis unit of tourism behavior was a three-piece set of the target (noun) of the behavior, the verb of behavior, and the particle that connects them. Their set obtained by the dependency analysis. By extracting such basic data and analyzing them by a statistical method, the typical noun was extracted with typical tourism behavior.

\section{EXTRACTION OF TOURIST BEhAVIOR}

\section{A. Tourist Behavior}

In many cases, tourists will do behavior similar at a tourist resort. We thought it possible to get to know behavior of tourism which is not contained in the existing tourism information by gathering such behavior. Tourism behavior is usually the combination of general action and its object. Therefore, we decided to describe tourism behavior by the set of an object and behavior.

We extract the noun $n_{i}$ with Verb $v_{k}$ and Particle $p_{j}$ first. We defined the set $\left(n_{i}, p_{j}, v_{k}\right)$ as behavior.

The behavior which appears in high frequency at the blog article about one area is surely behavior peculiar to the area. We call it tourism behavior.

\section{B. Ranking Method}

We consider evaluating the characteristic tourism behavior for every area. This paper evaluates the noun obtained as an object of behavior after fixing the particle and verb of tourism behavior.

Our previous study [12] performed evaluation by the number of the tourism behavior for every area. However, many general nouns have been extracted.

Therefore, the following two points were improved in this paper. The first point is using the deviation of the frequency of appearance of the noun for every area for evaluation. The second point is not having used tourism behavior for evaluation of a noun, but having used the frequency of appearance of the noun in the blog article of an area. Thereby, more information can be used now for selection of object.

This procedure is shown in the following.

1) Let $L$ be a set of the area for analysis, and let $\ell$ be an area belonging to $L$.

2) Let $S$ be a set of all blog articles, and let $s_{\ell}$ be a subset which consists of blog articles relevant to $\ell$ among $S$. 
3) We extract the noun which appears in blog article set $s_{\ell}$ with $p$ and $v$ by a Japanese dependency analysis. Let $N_{\ell}$ be the noun set. Moreover, let $N$ be the set union of $N_{\ell}$ for every $\ell$.

4) We count up number of occurrences Freq $\left(n_{i}, \ell\right)$ in $s_{\ell}$ for $n_{i} \in N$. We normalize it in the total of the blog articles of the area. Normalized $\operatorname{Freq}^{\prime}\left(n_{i}, \ell\right)$ is the following formula.

$$
\operatorname{Freq}^{\prime}\left(n_{i}, \ell\right)=\frac{\operatorname{Freq}\left(n_{i}, \ell\right)}{\left|s_{\ell}\right|} .
$$

5) For each noun $n_{i} \in N$, the deviation score DS of the number of occurrences for each area is calculated by the following formula.

$$
\operatorname{DS}\left(n_{i}, \ell\right)=\frac{10\left(\operatorname{Freq}^{\prime}\left(n_{i}, \ell\right)-\mu_{\ell}\right)}{\sigma_{\ell}}+50
$$

$$
\begin{aligned}
\text { where } \sigma_{\ell} & \neq 0, \\
\mu_{\ell} & =\frac{1}{|L|} \sum_{i=1}^{|L|} \operatorname{Freq}^{\prime}\left(n_{i}, \ell\right) \text { and } \\
\sigma_{\ell} & =\sqrt{\frac{1}{|L|} \sum_{i=1}^{|L|}\left(\operatorname{Freq}^{\prime}\left(n_{i}, \ell\right)-\mu_{\ell}\right)^{2} .}
\end{aligned}
$$

6) All nouns are sorted in order of deviation score DS, and nouns with large deviation score are taken up.

\section{BASIC DATA}

$7,917,385$ blog articles relevant to the Kyushu area were gathered using a Web crawler. The blog articles containing each prefecture name of Kyushu were extracted from them, and they were made into the information about each prefecture. The number of the blog articles about each prefecture is shown in Table I.

TABLE I

NUMBER OF BLOG ARTICLES

\begin{tabular}{cc}
\hline Area (Prefecture) & Number of Blog Articles \\
\hline Fukuoka & 152,421 \\
Saga & 22,042 \\
Kumamoto & 38,799 \\
Ooita & 76,580 \\
Nagasaki & 33,711 \\
Miyazaki & 38,954 \\
Kagoshima & 36,230 \\
Okinawa & 114,132 \\
\hline
\end{tabular}

\section{EXTRACTION AND ANALYSIS}

In this paper, we decided eight prefectures in the Kyushu area to be the targets for analysis. Furthermore, the following three points were noted as information relevant to the tourism of an area. (1) What is eaten in the area? (2) Where are they eaten in the area? (3) Destination. We tried extraction of this information. The blog articles of Sec. III were used as target data.

\section{A. What does a tourist eat there?}

At almost all tourist resorts, the specialty of an area is advertised, and a tourist eats them, or purchases it as a souvenir. However, there are many obscure local specialties ordinarily eaten in the area in addition to them. In recent years, the food which was not advertised as a specialty of an area attracts attention as new resources for tourism in many cases. The attempt which picks out an obscure specialty as new resources for tourism is performed, such as a contest called "Class B gourmet".

In this section, what is eaten regionally is clarified by extracting the target of the behavior "eat" in blog articles. Specifically, the noun were gathered with the particle “を" for the verb “食べる”.

Deviation score was calculated using the formula of the foregoing paragraph. Only the noun which appeared two times or more is the target of processing in order to avoid the rare occurrence of a word unrelated to the information on an area. 34 nouns had the same, highest deviation score. In order of the value of TF, the extracted noun is shown in Table II.

Most obtained nouns were what is eaten regionally as local specialties. These are felt more suitable than the noun extracted by previous study [12]. Although “沖縄限定品” and “沖縄ラ ンチ” are not the names of a concrete dish, they are generic descriptions of cooking. Therefore, they are simple to remove depending on necessity.

“牛さん豚さん” is not general description. It occurred frequently about the foot-and-mouth-disease damage generated in Miyazaki in 2010.

“一人ケーキ” and “たくさんごちそう” are the compounds which are not correct. Therefore, it is necessary to improve construction of the compound in a morphological analysis.

“郷土料理屋さん” has been extracted by the mistake in a dependency analysis.

\section{B. Where does a tourist eat there?}

As tourism information, the information where we eat is also important. Nouns with the particle which deduces a place The nouns depending on a verb "it eats". Therefore, we extracted nouns depending on verb “食べる” with the particle “で” which deduces a place.

The number of occurrences performed ranking using the valuation plan of the foregoing paragraph about two or more nouns. The extraction result of 30 higher ranks is shown in table III.

The names of stores and facilities which were appropriately extracted as a place of behavior to "eat" are the following 12 nouns: “ピロティー”, “福岡空港内”, “玖珠サービスエリア”, “梅月堂”, “長崎リンガーハット”, “熊本ワイン工場”, “長浜 将軍さん”, “重兵衛”, “菊井カツ”, “香港苑”, “鮨文” and “鹿 児島駅”.

Since “ポツポ市” and “鹿児島フェア” are event names, they will be useful information as the place of behavior to "eat". In addition, place names, i.e., “奥武島”, “東区若宮”, “中心部 天神”, “大嶺崎”, “沖縄市”, “長崎市内”, “大分市内”, “北谷” and “沖縄”, are useful in many cases. 
TABLE II

TARGET TO EAT

\begin{tabular}{|c|c|c|c|c|c|}
\hline Ranking & Deviation Score & TF & NG & Noun & Area \\
\hline 1 & 76.458 & 37 & & 中身汁 (Nakami-Jiru) & Okinawa \\
\hline 2 & 76.458 & 28 & & 牛汁 (Gyu-Jiru) & Okinawa \\
\hline 3 & 76.458 & 26 & & 海ブドウ (Umi-Budou) & Okinawa \\
\hline 4 & 76.458 & 13 & & 山原そば (Yanbaru-Soba) & Okinawa \\
\hline 5 & 76.458 & 7 & & 沖縄限定品 (Limited article in Okinawa) & Okinawa \\
\hline 5 & 76.458 & 7 & & 沖縄ランチ (Okinawa lunch) & Okinawa \\
\hline 5 & 76.458 & 7 & & ヤギ料理 (Goat dish) & Okinawa \\
\hline 5 & 76.458 & 7 & & 本場長崎ちゃんぽん (Nakasaki Chanpon) & Nagasaki \\
\hline 5 & 76.458 & 7 & $*$ & 牛さん豚さん (Ushi-san Buta-san) & Miyazaki \\
\hline 10 & 76.458 & 5 & & 木灰そば (Mokkai-Soba) & Okinawa \\
\hline 10 & 76.458 & 5 & & 手作り沖縄そば (Hand-made Okinawa Soba) & Okinawa \\
\hline 10 & 76.458 & 5 & & 熊本産馬刺し (Raw horse meat from Kumamoto) & Kumamoto \\
\hline 13 & 76.458 & 4 & & 名物シシリアンライス (Speciality Sicilian Rice) & Saga \\
\hline 13 & 76.458 & 4 & & 与那国ソバ (Yonaguni-Soba) & Okinawa \\
\hline 13 & 76.458 & 4 & & サイミン (Saimin) & Okinawa \\
\hline 13 & 76.458 & 4 & & 半額麺 (Noodles at half price) & Fukuoka \\
\hline 17 & 76.458 & 3 & & 宮崎産牛 (Beef from Miyazaki) & Miyazaki \\
\hline 18 & 76.458 & 2 & $*$ & 一人ケーキ (Eating a cake alone) & Saga \\
\hline 18 & 76.458 & 2 & & 卵掛けご飯 (Cooked rice with a fresh egg) & Ooita \\
\hline 18 & 76.458 & 2 & & 水宇治金時 (Chipped ice) & Ooita \\
\hline 18 & 76.458 & 2 & & あなご重 (Broiled eels on rice) & Ooita \\
\hline 18 & 76.458 & 2 & & 350 円お弁当 (Cheap box lunch) & Ooita \\
\hline 18 & 76.458 & 2 & & 白味噌ラーメン (Siro-Miso-Ramen) & Okinawa \\
\hline 18 & 76.458 & 2 & $*$ & 郷土料理屋さん (Regional specialties restaurants) & Okinawa \\
\hline 18 & 76.458 & 2 & & 沖縄ちゃんぽん井 (Okinawa Changpon Don) & Okinawa \\
\hline 18 & 76.458 & 2 & & モズクてんぷら (Mozuku Tenpura) & Okinawa \\
\hline 18 & 76.458 & 2 & & タコせんべい (Tako Senbei) & Okinawa \\
\hline 18 & 76.458 & 2 & $*$ & たくさんごちそう (Many dishes) & Okinawa \\
\hline 18 & 76.458 & 2 & & 宮崎黒毛和牛 (Miyazaki premium beef) & Miyazaki \\
\hline 18 & 76.458 & 2 & & 宮崎マンゴードロップ (Mango Drops) & Miyazaki \\
\hline 18 & 76.458 & 2 & & 年越し魚 (Year-crossing fishes) & Kumamoto \\
\hline 18 & 76.458 & 2 & & 焼サバ寿司 (Baked mackerel sushi) & Kumamoto \\
\hline 18 & 76.458 & 2 & & 南米風レッドカレー (Red curry of the South America style) & Fukuoka \\
\hline 18 & 76.458 & 2 & & ねぎ井 (Welsh onion bowl) & Fukuoka \\
\hline
\end{tabular}

“花安謝店” and “思案橋店” are parts of store names, respectively, and are unsatisfactory as information. About 花安 謝店, it is failure of a dependency analysis. The store name was “だいこんの花安謝店”. “思案橋店” is only the branch name part of a store. Although it is not a mistake, the procedure which restores the whole store name is needed. They are not suitable although the “神戸オフィス” and “機張” (South Korean place-name) are the names of a place of behavior to "eat".

“干しイカ” and “焼加減” are the descriptions showing the state of foods. They were extracted in order that a particle " で” might lead the noun showing a state. “膳瀬” is the name of a person extracted by the mistake in a dependency analysis.

You can identify that the scores of Table III are hardly different. Furthermore, the kind of noun changes also with values of TF (Term Frequency). Another rate scale which combined Deviation Score and TF may be necessity.

\section{Where does a tourist go there?}

The destination for every area is also important. The place to which many people go may be tourism spot. We extracted nouns depending on verb “行く” with the particle “に”.

The number of occurrences performed ranking using the valuation plan of the foregoing paragraph about two or more nouns. The extraction result of 30 higher ranks is shown in Table IV.

The tourism spot, events, and stores which were appropriately extracted as a destination were the following 19 nouns: " 奥武島”, “沖縄市民会館”, “産業祭り”, “西大分駅”, “サンエー 経塚シティー”, “福岡魂”, “湯平温泉”, “福岡サンパレスホー ル”, “府内戦紙”, “サンマリンスタジアム宮崎”, “全島エイ サ一祭り”, “ゴリラチョップ”, “長崎ペンギン水族館”, “宮崎 港”, “大分七夕祭り”, “沖縄物産店”, “力スタムカーショー”, “長崎ちゃんめん” and “生活文化展”.

The particle “に” also has the function which indicates a reason in addition to a destination.“沖縄口ケ”, “沖縄家族旅 行” and “沖縄取材” were extracted by the function. Separation of them is a future task.

The remaining words are general place-names. They are suitable as a destination. However, it is depended on the purpose whether it is useful as resources of tourism. If there is necessity, we can remove them using the existing place-name 
TABLE III

Place of the ACt to EAT

\begin{tabular}{|c|c|c|c|c|c|}
\hline Ranking & Score & TF & NG & Noun & Area \\
\hline 1 & 76.458 & 121 & & 奥武島 (Ou-jima) & Okinawa \\
\hline 2 & 76.458 & 19 & * & 花安謝店 (Hana-aja-ten) & Okinawa \\
\hline 2 & 76.458 & 19 & & ピロティー (Pilotis) & Okinawa \\
\hline 4 & 76.458 & 17 & & 東区若宮 (Higashi-ku Wakamiya) & Fukuoka \\
\hline 5 & 76.458 & 16 & & 福岡空港内 (Inside of Fukuoka Airport) & Fukuoka \\
\hline 6 & 76.458 & 14 & $*$ & 膳瀬 (Zense) & Ooita \\
\hline 7 & 76.458 & 7 & & 中心部天神 (Central city, Tenjin) & Fukuoka \\
\hline 8 & 76.458 & 5 & & 玖珠サービスエリア (Kusu service area) & Ooita \\
\hline 8 & 76.458 & 5 & & ポッポ市 (Poppo Fair) & Okinawa \\
\hline 8 & 76.458 & 5 & & 梅月堂 (Baigetsudo) & Nagasaki \\
\hline 8 & 76.458 & 5 & $*$ & 神戸オフィス (Kobe office) & Fukuoka \\
\hline 8 & 76.458 & 5 & $*$ & 機張 (Gijang) & Fukuoka \\
\hline 13 & 76.458 & 4 & & 大嶺崎 (Ufun-mizachi) & Okinawa \\
\hline 13 & 76.458 & 4 & & 長崎リンガーハット (Nagasaki Ringer Hut) & Nagasaki \\
\hline 15 & 76.458 & 3 & & 熊本ワイン工場 (Kumamoto wine brewery) & kumamoto \\
\hline 15 & 76.458 & 3 & & 長浜将軍さん (Pub Nagahama shogun) & Fukuoka \\
\hline 15 & 76.458 & 3 & & 重兵衛 (Jubee) & Fukuoka \\
\hline 18 & 76.458 & 2 & & 菊井カツ (Kikui-katsu) & Okinawa \\
\hline 18 & 76.458 & 2 & $*$ & 干しイカ (Hoshi-ika) & Okinawa \\
\hline 18 & 76.458 & 2 & $*$ & 思案橋店 (Shianbashiten) & Nagasaki \\
\hline 18 & 76.458 & 2 & & 香港苑 (Hongkongyen) & kumamoto \\
\hline 18 & 76.458 & 2 & & 鮨文 (Sushibun) & Fukuoka \\
\hline 18 & 76.458 & 2 & * & 焼加減 (A baked condition) & Fukuoka \\
\hline 24 & 76.456 & 5800 & & 沖縄市 (Okinawa City) & Okinawa \\
\hline 25 & 76.455 & 717 & & 長崎市内 (Inside of Nagasaki) & Nagasaki \\
\hline 26 & 76.452 & 1157 & & 大分市内 (Inside of Ooita) & Ooita \\
\hline 27 & 76.451 & 2712 & & 北谷 (Chatan) & Okinawa \\
\hline 28 & 76.449 & 10 & & 鹿児島フェア (Kagoshima Fair) & Kagoshima \\
\hline 29 & 76.448 & 234 & & 鹿児島駅 (Kagoshima Station) & Kagoshima \\
\hline 30 & 76.446 & 175624 & & 沖縄 (Okinawa) & Okinawa \\
\hline
\end{tabular}

where * are marked on unsuitable (NG) extraction.

dictionary.

The method of this paper chiefly extracted only concrete destinations compared with our previous study [12]. However, in order to extract more destinations for tourism, the classification method which used the ranking is required.

\section{RELATED WORK}

We can find tourism information on Web in (a) tourism portal sites, in (b) general web pages, and in (c) blog articles. There are several systems and researches intended for each target.

Esparcia et al. [2] proposed a recommendation and a clustering system, and showed their effectiveness for tourism portals. Ruiz-Martinez et al. [10] developed a natural language interface for tourism search engine. Saito and Ohuchi [11] proposed "keymaps" that visualizes co-occurrences of keywords in tourism documents. Kinjo and Ohuchi [6] analyzed the patterns in HTML documents that characterize the occurrences of NEs(Named Entity), such as the name of the location and the name of the tourism events. Hao et al. [3] and Ozaku et al. [9] studied the clue words that can be used to extract tourism related to NEs. Ishino et al. [5] reported the characteristic keywords that distinguish tourism blogs from other general blogs. Okumura et al. [8] proposed the method to extract and classify strong points in sightseeing area as support techniques to develop sightseeing area. Wu et al. [13] reported the difference between tourism information which a local government offers, and tourism information written in blog articles. Hirokawa et al. [4] proposed a search engine that focuses on the usage of onomatopoeic words that appear on tourism blogs. Yin et al. [15], [14] proposed the method of searching a characteristic tourism event in each area. The purpose of this paper is extraction of concrete behavior of tourism, and differs from these studies.

Aizawa and Nakawatase [1] tried the automatic extraction of synonyms with sample phrases using dependency analysis of text. Although this paper also uses a dependency analysis for information extraction, collection of synonyms is not the purpose.

\section{CONCLUSION AND FutURE WORKS}

We have been working on content extraction of tourism blogs by dependency analysis of verbs, particles and nouns. This paper used the deviation of frequencies as an evaluation measure of nouns that are used for the object of the verb. The proposed method performed better than the previous method by the authors in extracting many and interesting nouns. On the other hand, the clues of the extraction in this paper are only 
TABLE IV

DESTINATION

\begin{tabular}{|c|c|c|c|c|c|}
\hline Ranking & Score & TF & NG & Noun & Area \\
\hline 1 & 76.458 & 121 & & 奥武島 (Ou-jima) & Okinawa \\
\hline 2 & 76.458 & 88 & * & 沖縄ロケ (Location shoot in Okinawa) & Okinawa \\
\hline 3 & 76.458 & 83 & & 沖縄市民会館 (Okinawa Civic Hall) & Okinawa \\
\hline 4 & 76.458 & 80 & & 産業祭り (Industrial Festival) & Okinawa \\
\hline 5 & 76.458 & 68 & & 大分市中心部 (Ooita pivot) & Ooita \\
\hline 6 & 76.458 & 66 & & 西大分駅 (Nishi-Ooita station) & Ooita \\
\hline 7 & 76.458 & 56 & * & 沖縄家族旅行 (Okinawa family travel) & Okinawa \\
\hline 8 & 76.458 & 50 & & サンエー経塚シティー (Hypermarket, San-A kyouzuka city) & Okinawa \\
\hline 8 & 76.458 & 50 & & 福岡県行政書士会 (Fukuoka Gyoseishoshi Lawyers Association) & Fukuoka \\
\hline 10 & 76.458 & 39 & & 福岡魂 (Fukuoka Soul) & Fukuoka \\
\hline 10 & 76.458 & 39 & & 総合図書館 (General Library) & Fukuoka \\
\hline 12 & 76.458 & 38 & & 湯平温泉 (Yunohira Spa.) & Ooita \\
\hline 13 & 76.458 & 36 & & 長崎県南島原市 (Minami-Shimabara city) & Nagasaki \\
\hline 14 & 76.458 & 33 & & 福岡サンパレスホール (Fukuoka Sunpalace Hole) & Fukuoka \\
\hline 15 & 76.458 & 32 & & 先日鹿児島 (Kagoshima on the other day) & Kagoshima \\
\hline 15 & 76.458 & 32 & & 福岡市総合図書館 (Fukuoka City Public Library) & Fukuoka \\
\hline 17 & 76.458 & 30 & & 府内戦紙 (Funai Patchin) & Ooita \\
\hline 17 & 76.458 & 30 & & サンマリンスタジアム宮崎 (Sun Marine Stadium Miyazaki) & Miyazaki \\
\hline 19 & 76.458 & 28 & & 全島エイサー祭り (Okinawa Zento Eisa Matsuri) & Okinawa \\
\hline 20 & 76.458 & 27 & & ゴリラチョップ (Gorilla chop) & Okinawa \\
\hline 20 & 76.458 & 27 & & 長崎ペンギン水族館 (Nagasaki Penguin Aquarium) & Nagasaki \\
\hline 20 & 76.458 & 27 & & 宮崎港 (Miyazaki Port) & Miyazaki \\
\hline 23 & 76.458 & 26 & & 大分七夕祭り (Tanabata Festival) & Ooita \\
\hline 23 & 76.458 & 26 & & 大分県サッカー協会 (Ooita Football Association) & Ooita \\
\hline 23 & 76.458 & 26 & & 沖縄物産店 (Okinawa product store) & Okinawa \\
\hline 23 & 76.458 & 26 & & カスタムカーショー (Fukuoka Customcar Show) & Fukuoka \\
\hline 27 & 76.458 & 25 & & 大分商業高校 (Ooita Commercial High School) & Ooita \\
\hline 27 & 76.458 & 25 & & 長崎ちゃんめん (Nagasaki chanmen) & Nagasaki \\
\hline 29 & 76.458 & 24 & & 生活文化展 (Life culture exhibition) & Ooita \\
\hline 30 & 76.458 & 23 & $*$ & 沖縄取材 (Okinawa coverage) & Okinawa \\
\hline
\end{tabular}

where * are marked on unsuitable (NG) extraction.

three pairs of a particle and a verb. In order to extract tourism behavior appropriately, it is necessary to evaluate much more pairs. Moreover, the range of suitable extraction needs to be detected instead of 30 higher ranks. We plan to create a tourism resource extraction system for blogs based on tourists' behavior.

\section{REFERENCES}

[1] A. Aizawa and H. Nakawatase, "Automatic extraction of synonyms with sample phrases using dependency analysis of text and its application to large-scale corpora," in the 20th Annual Conference of the Japanese Society for Artificial Intelligence, 2E1-5, 2006. (in Japanese)

[2] S. Esparcia, V. Sanchez-Anguix, E. Argente, A. Garcia-Fornes and V. Julian, "Integrating Information Extraction Agents into a Tourism Recommender System," in Proc. HAIS2010, Springer LNAI 6077, pp.193-200, 2010.

[3] Q. Hao, R. Cai, Ch. Wang, R. Xiao, J.-M. Yang, Y. Pang and L. Zhang, "Equip Tourist with Knowledge Mined from Travelogues," in Proc. WWW2010, pp.401-410, 2010.

[4] S. Hirokawa, C. Yin, K. Hashimoto and K. Takeuchi, "Search and Analysis of Gourmet Blogs with a Particular Reference to Onomatopoeia," ICIC Express Letters, Volume 5, Issue 8(B), pp.2971-2976, 2011.

[5] A. Ishino, H. Nanba, H. Gaguma, T. Ozaki, D. Kobayashi and T. Takezawa, "Automatic Compilation of Travel Information from Automatically Identified Travel Blogs," IEICE Tech Report, WI2-2009, pp.1923, 2009.(in Japanese)

[6] I. Kinjo and A. Ohuchi, "Web data analysis for Hokkaido tourism information," IEICE Tech. Report, DE2001-07, pp.99-104, 2001. (in Japanese)
[7] T. Kudo and Y. Matsumoto, "Fast Methods for Kernel-Based Text Analysis," Proceedings of the 41st Annual Meeting on Association for Computational Linguistics-Volume 1, pp.24-31, 2003.

[8] H. Okumura, M. Tokuhisa, J. Murakami and M. Murata, "Trial of extracting and classifying strong points in sightseeing area," IEICE technical report. Natural language understanding and models of communication 110(245), pp.25-30, 2010. (in Japanese)

[9] H. Ozaku, M. Utiyama and M. Kidode, "An Event Information Retrieval Method Using Features of Keyword Appearance in Newspaper Corpora," Trans. JSAI, AI19, pp.225-233, 2004. (in Japanese)

[10] J. M. Ruiz-Martinez, D. Castellanos-Nieves, R. Valencia-Garcia, J. T. Fernandez-Brieis, F. Garcia- Sanchez, P. J. Vivancos-Vincente, J. S. Castejon-Garrido, J. B. Camon and R. Martinez-Bejar, "Accessing Touristic Knowledge Bases through a Natural Language Interface," Springer LNAI 5465, pp.147-160, 2009.

[11] H. Saito and A. Ohuchi, "A Study of Visualizing Method of WWW Documents to Construct the Concept on Sightseeing Information," IEICE Tech. Report, DE2001-07, pp.261-267, 2001. (in Japanese)

[12] T. Nakatoh, C. Yin and S. Hirokawa, "Characteristic Grammatical Context of Tourism Information," ICIC Express Letters, Vol.6, No.3. March 2012, pp.753-758, 2012.

[13] X. Wu, S. Hirokawa, C. Yin, T. Nakatoh and Y. Tabata, "Extraction and Comparison of Tourism Information on the Web," in Proc. of AROB2011, 2011.

[14] C. Yin, T. Nakatoh, S. Hirokawa, X. Wu and J. Zeng, "A proposal of search engine "XYZ" for tourism events," Second IITA International Joint Conference on Artificial Intelligence, 2010.

[15] C. Yin, X. Wu, S. Hirokawa and T. Nakatoh, "A Proposal of 'TOIEBA' Search Engine for Tourism Event," IEICE technical report. Artificial intelligence and knowledge-based processing vol. 110, no. 301, pp.4347, 2010. (in Japanese) 